\title{
Teachers judging without scripts, or thinking cosmopolitan
}

\author{
Sharon Todd* \\ Stockholm Institute of Education, Sweden
}

\begin{abstract}
A cosmopolitan ethic invites both an appreciation of the rich diversity of values, traditions and ways of life and a commitment to broad, universal principles of human rights that can secure the flourishing of that diversity. Despite the tension between universalism and particularism inherent in this outlook, it has received much recent attention in education. I focus here on one of the dilemmas to be faced in taking cosmopolitanism seriously, namely, the difficulty of judging what is just in the context of an increasingly divergent public - and classroom-discourse about values, rights and equality. I propose in what follows that judgement cannot rely on any script, even one as attractive, perhaps, as cosmopolitanism. To explore what is at stake in making judgements in an educational context, I draw on both Hannah Arendt's and Emmanuel Levinas's notions of judgement and thinking. The paper discusses the educational significance of thought and judgement as conditions for reframing the universalism-particularism problem found in a cosmopolitan ethic. My argument is that there is a world of difference between educating for cosmopolitanism, which entails a faith in principles, and 'thinking cosmopolitan', which entails a hope in justice for my neighbours.
\end{abstract}

\section{Keywords: Cosmopolitanism; Judgement; Thinking; Arendt; Levinas; Teachers;} Universalism; Particularism

\section{Introduction}

Particular questions must receive particular answers; and if the series of crises in which we have lived since the beginning of the century can teach us anything at all, it is, I think, the simple fact that there are no general standards to determine our judgments unfailingly, no general rules under which to subsume the particular cases with any degree of certainty. (Hannah Arendt, 1966 speech, quoted in Arendt, 2003, p. vii)

What is inhuman is to be judged without there being anyone that judges. (Levinas, 1987, p. 40)

\footnotetext{
*Department of Social and Cultural Studies, Stockholm Institute of Education, Konradsbergsgatan 24, 10026 Stockholm, Sweden. Email: Sharon.todd@lhs.se
} 
Cosmopolitanism - an idea that has captured the Western imagination on and off for the past 2000 years - is now enjoying a renaissance. Its current appearance on the European scene occurs at a time when sensibilities around European belonging are particularly keen. Despite the difficulty of defining it, ${ }^{1}$ cosmopolitanism comprises, in both its historical and current invocations, a political and ethical mission to embrace a sense of worldliness outside the confines of national belonging, where our neighbours are no longer those who are 'just like us', but who exist in a global, as opposed to a national, neighbourhood. It is a shift away from patriotism - 'the virtue of the vicious,' as Oscar Wilde once quipped - toward a new understanding of our place and loyalties in the world. Thinkers such as Ulrich Beck (2006), Peter Kemp (2005), and Karl-Otto Apel (2000) even posit that the future of Europe depends upon our capacity to embrace a cosmopolitan 'ethic' and to begin to think differently about our belonging in the world. ${ }^{2}$

But what constitutes the kind of thinking they are wishing Europeans to take up in this ethic? And what difficulties does this raise for teachers who are being called upon to educate youth along the lines of this ethic? Cosmopolitanism reveals a commitment to notions of 'world', 'transnational' or 'global' citizenship, and also frames its pursuit of global justice largely along two lines: universal rights, on the one hand, and a respect for diversity, on the other, both of which trace their modern lineage to Kant's understanding of cosmopolitanism in his 1795 essay, Perpetual Peace. A cosmopolitan ethic invites both an appreciation of the rich diversity of values, traditions, and ways of life as part of the human condition and a commitment to broad, universal principles that can secure the flourishing of that diversity. In encouraging an openness toward others - their cultures, their values - and in seeking justice that moves beyond the narcissism of the nation-state, a cosmopolitan ethic has much to offer us in education, particularly those of us concerned with the ethical dimensions of living in multicultural societies in an era marked by globalization. ${ }^{3}$

Yet, I wish to raise two concerns here that are central for thinking about what relationship a cosmopolitan ethic might have to education. The first one has not so much to do with the inherent tension found within the ethic itself, but how it has failed to be adequately addressed. That is, there is a simultaneous appeal to embrace human rights (which entails a universalist ethic) and to respect cultural differences (which entails an eminently more particularistic emphasis) within cosmopolitanism. This double demand inevitably creates a contradictory logic that cannot be remedied by emphasising one commitment over the other without, it seems to me, sacrificing the project of cosmopolitanism itself. ${ }^{4}$ Rather than suggesting, as has been the tendency with those who support cosmopolitanism, that human rights simply trump all other cultural values as a condition of transnational belonging (e.g. Apel, 2000; Anderson-Gold, 2001; Nussbaum, 2003; Kemp, 2005), ${ }^{5}$ I think this contradictory logic is really begging a different ethical question: for is it not more a matter of how we adjudicate in concrete circumstances, across our differences and in light of rights, that is really at stake here? It seems to me that privileging rights on principle denies the very cornerstone of human plurality upon which cosmopolitanism 
is usually grounded. Similarly, prioritising all aspects of diversity within cultures, traditions, and beliefs over rights seems to land us in the proverbial relativist morasse. My suggestion here is instead to make the difficulties of judgement itself a central part of any cosmopolitan outlook.

My second concern has to do with this cosmopolitan ethic (or any ethic, for that matter) becoming yet another script that teachers or anyone else should supposedly recite, as though it held all the answers to our human predicament in the twenty-first century. Teachers in particular are frequently bombarded with various kinds of directives that are supposed either to 'help' their practice in becoming better teachers or to be 'implemented' in the name of a better future. The problem with this application model of theory to practice is that it risks leaving out of the equation the here-and-now realities in which teachers are engaged, and it also risks encouraging an uncritical - dare I say thoughtless - stance toward those ideas that are meant to be implemented. With the case of the inherent contradiction within cosmopolitanism, this is particularly evident in terms of how teachers negotiate reconciling their commitment to respecting the diversity of values and traditions with their commitment to universal principles. My point is that if we are going to concede that cosmopolitanism has something important to say with regard to how education might be rethought beyond the nation-state, then it behoves us to consider the whole question of how teachers might live justly within the aporetic space created by a dual commitment to transnational, universal principles of human rights and an attentiveness to the unsettling play of cultural and social diversity.

I focus here on one of the dilemmas to be faced in taking cosmopolitanism seriously, namely the difficulty of judging what is just in the context of an increasingly divergent public - and classroom-discourse about values, rights and equality. In other words, how might judgement help us to think differently about the relation between education and cosmopolitanism beyond the script of a cosmopolitan ethic? I propose in what follows that everyday teaching practices and the difficulties of judgement that teachers face are themselves tied already to what Kant referred to as our 'cosmopolitan existence'. In this sense, teaching can be seen as being implicated in a cosmopolitan approach, as opposed to being the vehicle through which a cosmopolitan ethic is implemented. To explore what is at stake in making judgements in an educational context, I draw on both Hannah Arendt's and Emmanuel Levinas's notions of judgement and thinking. What both emphasise is the strong connection between our capacity for thought and our capacity to judge as conditions arising from human plurality, from our 'cosmopolitan existence'. As Kant himself identified, cosmopolitanism as an expression of respecting diversity and according others absolute rights demands a capacity for 'enlarged mentality', or, in other words, a capacity to think beyond oneself in order to judge. Thus, what I explore here is the educational significance of thought and judgement as conditions for reframing the universalism-particularism problem found in a cosmopolitan ethic. My argument is that there is a world of difference between educating for cosmopolitanism, which entails a faith in principles, and 'thinking cosmopolitan', which entails an aspiration for justice for my neighbours. Indeed, by placing thinking 
at the heart of judgement, I wish to mobilise a notion of thought that resists scripts, even those as seductive as cosmopolitanism. For the question remains, how do we promote a particular project of global justice without turning it into a prosthesis for thinking?

\section{Teaching, judging, thinking}

There are two aspects of teaching and judging I wish to draw out here in order to situate them in relation to cosmopolitanism: first, that teaching is inherently involved in making judgements; and secondly, that judgement is central to justice. With respect to the former, the judgement of teachers is perhaps most obvious in matters of assessment and evaluation; but it is in facing the range of human diversity in their classrooms that teachers' judgements are an everyday matter, constantly deciding, evaluating, comparing and prioritising students' competing individual demands and needs. More often than not, such judgements happen without much reflection: the immediacy of their required response often does not allow teachers much time for thinking. Instead, relying on well-worn strategies and rules of engagement, teachers frequently perform their professional role like a character in an old, familiar play. Such rules help teachers to respond quickly, efficiently; and I certainly appreciate the need for teachers to do so. However, strictly speaking, a judgement is precisely that which cannot be made by adhering, relatively unthinkingly, to a rule or principle. It requires decision, by a singular subject, by a teacher as an individual who, in her particular encounters with others, says 'I decide'. Thus it is not a role we are talking about when we talk about judgement in this sense, but a person who, although a professional and part of a profession, makes decisions in all her singularity. Indeed, in my experience, teachers frequently discuss these differences in decision-making in terms of the tensions they face in the classroom between making decisions as teachers and making decisions as 'persons'. It is as though the role at times speaks through them as opposed to their speaking through the role. But at the end of the day, to echo Levinas, roles do not judge; there is something inhuman about claiming that there is no one, no person, who judges.

Regarding the second point, judgement is also that which is a necessary, if difficult, condition of justice, thus making the practice of judging in teaching a practice of justice as well. Judgements are statements of our prioritised responsibilities and of the results of our weighing the elements of a situation in order to reach a verdict. They say something about us to the world, and thus signal our own implication in it. That is, being able to decide who speaks when and to whom; giving priority over one student's story over another's; judging the truth value of what a student is telling you; deciding whether or not to punish a particular act of disobedience; assessing when a student's behaviour warrants a call home; protecting one student from harm at the hands of others; judging how to respond to disruption; deciding if a particular behaviour is racist or sexist, and if so, how to handle it - all these and more illustrate times when our judgements as teachers are actually partaking of something more 
than general rules or regulations can account for. They are decisions made about particular cases, which at the very least require interpretation of rules, and at most sometimes demand abandoning them altogether. As Arendt has warned us, if we have learned anything from the horrors of the twentieth century, it is not to put so much faith and trust in rules as the safeguards to our actions. Instead, what we need to reflect on is how judgement demands thinking beyond the standard scripts. That is, to think about our roles as opposed to letting those roles determine our thinking. This is particularly acute when it comes to a seemingly benevolent script such as cosmopolitanism, for it simply cannot provide the answers it sometimes professes to be able to offer. This means we need to reconsider what is at stake in our judgements as teachers with respect to others, and it means assessing the place of thinking in judgement more generally.

\section{Lessons from evil}

No philosopher has generated as much controversy, perhaps, as Hannah Arendt has done with her phrase 'the banality of evil'. A discussion on the place of thinking in judgement ironically must begin with this and its appearance in Arendt's report on the notorious 1961 trial of Adolf Eichmann. Arendt claims in a postscript written a year after the initial publication of Eichmann in ferusalem (Arendt, 1994) that she was merely offering an account 'strictly on the factual level' of phenomena she witnessed daily at the trial in coining the phrase. Here, Arendt for the first time develops the idea that it is the sheer inability to think that enables someone to perpetrate evil acts. No demoniacal possession, no diabolical depth: Arendt attributes simply (!) a thoughtlessness, a superficiality, and a 'remoteness from reality' (Arendt, 1994, p. 288) to Eichmann's comportment throughout the trial, and in particular the detached way in which he used language, unthinkingly parroting stock phrases without any sense of what they seemed to be signifying. Arendt notes that even at the gallows, moments before his execution by hanging, Eichmann's last words to the world are a series of contradictory clichés strung together. As Shoshana Felman (2002) notes, 'Eichmann does not speak the borrowed (Nazi) language: he is rather spoken by it, spoken for by its clichés, whose criminality he does not come to realize' (p. 213).

It is precisely this chilling inability to recognise human consequences, to weigh and to judge authentically beyond a mere parroting of rules, that is, for Arendt, one of the hallmarks of Nazi Germany. Although Arendt identified evil in all its banality, she did not assume that evil was ordinary; neither did she think that it did not have a unique human face. The danger with asserting that 'there is an Eichmann in us all', or that one was merely following orders (what Arendt refers to as the 'cog-theory of evil'), or that one shouldn't judge 'lest ye be judged' or that one cannot judge because one wasn't there, is the assumption that there is no unique agent - and therefore, nothing human-about the deeds being committed. Indeed, ironically, these ideas fall in precisely with Eichmann's defence: that evil deeds are not committed by a person, 
but that a person's role is merely the vehicle through which such deeds are enacted (if it was not me, then it would be someone else-what Zygmunt Bauman refers to as responsibility 'floated' [1993, p. 18]). Arendt is adamant that it is the individual who is to be judged and that judging requires seeing the one being judged in her or his humanity. Indeed, commenting on the apparent fear people seem to have about judging, Arendt claims that 'behind the unwillingness to judge lurks the suspicion that no one is a free agent, and hence the doubt that anyone is responsible or could be expected to answer for what he has done' (Arendt, 2003, p. 19).

The Eichmann case taught Arendt two important lessons: that the absence of independent thought in relation to words, to rules, to standards, leads to a failure of judgement and that the apparent easiness of this absence should indicate a deep suspicion about how rules and standards themselves function. With respect to the latter point, she writes:

[I]t was as though morality, at the very moment of its total collapse within an old and highly civilized nation, stood revealed in the original meaning of the word, as a set of mores, of customs and manners, which could be exchanged for another set with no more trouble than it would take to change the table manners of a whole people. (Arendt, 2003, p. 43)

Thus, for Arendt, it is perilous to be complacent and take any rules or standards at face value; she claims that we need 'to start thinking and judging instead of applying categories and formulas which are deeply engrained in our mind...' (Arendt, 2003, p. 37). Insofar as general rules of morality are 'taught and learned until they grow into habits' (Arendt, 2003, p. 189), they will always risk leading us awry unless we have the ability to consider the particular case from outside the terms of the universal. So, for Arendt, it is not so much that thoughtlessness leads to bad judgement: rather, it leads to no judgement at all.

Before moving on, I want to sum up what I see, in turn, as Arendt's lessons for education: first, that we would do well to think better of educating values as 'habits of mind' (including those cosmopolitan values that we find compelling) for, even when we think our values are best, we must recognise that we are not necessarily educating for thinking; and secondly, that making judgements, in Arendt's sense of the word, requires us to think, which means that judgements must be re-personalised even as they are made within the context of our roles as teachers. Thus, Arendt challenges the idea that education can ever be the fulfilment of an '-ism'-at least not without risking thoughtlessness, and perhaps even evil. But how are judgements made exactly, and what has this to do with thinking and promoting more just relations to others, both within and outside the classroom?

\section{Thinking for judgement}

At first blush, it is easy to see how thinking and judgement might be linked here. One reflects on the standards or the rules one is called upon to use in order to inform one's decisions about what to do with particular cases. To some degree, this is the 
relation Arendt proposes; but it is not the whole story. For do not thinking and judgement actually do different things?

In depicting how judgements are made, Arendt wishes to move out from underneath the history of philosophy-and religion-which centres the self as a unified entity isolated from others in making judgements. Taking issue with such prescriptions as 'Love thy neighbour as thyself', Arendt sees that there is a type of narcissism at play: the self as centre of the world as opposed to the self as being in the world with others. So, although she proposes that 'morality concerns the individual in his singularity' (Arendt, 2003, p. 97), it is a funny sort of singularity in that the self exists in the plural: I am 'I' as I appear to others, and I am also 'myself' to myself. Thus being different is part of the very nature of the self-all things identical with themselves are at the same time different from what they are not. ${ }^{6}$

Thinking, for Arendt, is therefore the conversation the ' $\mathrm{I}$ ' has with itself. It needs no others to engage with; it is, in fact, a necessary retreat from the world of appearances. Thinking is not an activity like others, like an action upon the world, but an internal conversation that has the job of representing to the self things in the abstract: it deals with invisibles. Moreover, thinking does not lead to any 'solid axioms'. As Arendt writes, 'we cannot expect any moral propositions or commandments, no final code of conduct from the thinking activity, least of all a new and now allegedly final definition of what is good and what is evil' (Arendt, 2003, p. 167). Thinking is a meditation, a resultless enterprise not fixated on deliberating, or reaching conclusions. It examines unceasingly all creeds, suppositions, standards, and rules. In this sense, thinking poses a danger to established thought. Yet, the alternative cannot lie in discouraging thinking:

By shielding people against the dangers of examination, it teaches them to hold fast
to whatever the prescribed rules of conduct may be at a given time in a given society.
What people then get used to is not so much the content of the rules... as the possession
of rules under which to subsume particulars. (2003, p. 178)

The radicality of Arendt's conception of thinking lies in the acknowledgement that thinking 'does society little good ... it does not create values, it will not find out, once and for all, what "the good" is, and it does not confirm but rather dissolves accepted rules of conduct' (2003, p. 188). This begs the question of how we reconcile thinking with judgement when the latter seems to be very much about deciding as opposed to restlessly ruminating.

Judgement is not about invisibles, but is concerned with actual persons and circumstances. It is the arbiter of right and wrong in particular cases. Judgement requires that I take others into account, and although I do not conform to their judgements (indeed blindly doing so would not be judgement at all), Arendt is clear that judgement is not purely subjective. I do not simply take my own thinking into account, but those others who are prepared to judge themselves. It is here that Arendt establishes the importance of community between fellow judges. Thus, it is with them that I am in a community of common sense-what Arendt, following Kant, calls 'the mother of judgement'. It is this intersubjectivity that keeps 
judgement alive, and not the solo performance of the thinking ego. Judgement is, quite simply, an engagement in a world rich with diversity; it is a cosmopolitan activity. Commenting on Kant, Arendt writes: 'One judges always as a member of a community, guided by one's community sense, one's sensus communis. But in the last analysis, one is a member of a world community by the sheer fact of being human; this is one's "cosmopolitan existence" (Arendt, 1992, p. 75).

So, how could thinking be related to judgement if the former is always about invisibles, the latter about particular, lived circumstances in a manifold human landscape, a specifically cosmopolitan landscape? Arendt claims that judgement is the 'by-product of the liberating effect of thinking' (Arendt, 2003, p. 189); thinking kicks off, as it were, this engagement with the world. It is thus that judgement becomes a realization of thinking (Arendt, 2003, p. 188): it is in this sense both determinant and reflexive. Nevertheless, it is not clear to me why thinking has such power to jump-start the faculty of judgement. Indeed, it is not clear how the solitariness of thinking lends itself to the social, intersubjective sphere of judging. What moves me out of my solitude to come back to the world and offer my judgement? ${ }^{7}$ Given that Arendt's claim is that judgement requires thought to mobilize it-for without thought, we are back to non-judgement and evil-there is a piece missing from her picture that distorts, I think, the place judgement has in our relations to others. It is a particularly important relation that, in my view, has vital consequences for teaching in general and for 'thinking cosmopolitan' in particular.

\section{The provocation of the other}

I believe Arendt is correct in assuming that thinking is a dangerous, critical enterprise, particularly in times of moral and political conformity. And I agree that thinking is, at least in part, a resultless, restless conversation that I have with myself, and is, by its nature, not of society in the same way that our other activities are. Yet, although I might think in solitude, I want to challenge the idea that thinking derives wholly from myself. Arendt was correct in identifying that alterity, or difference, is fundamental to the internal conversation, but in my view that alterity comes from something exterior to the self-it is precisely what is not-me that enables conversation-whether that conversation happens internally or otherwise. I want to spend a little time on this here, drawing on the work of Levinas, in order to develop the view that it is precisely because thought comes from the other and not from myself that thinking can be seen to be essential to judgement, and to justice more generally.

It is perhaps helpful to begin this tack with a depiction of what thinking is not. Levinas (1987) writes: 'A particular being can take itself to be a totality only if it is thoughtless. Not that it is deceiving itself or thinking badly or foolishly; it is not thinking' (p. 25). This particular being that does not think is what Levinas (1987) calls a living being - a being who lives in 'ignorance of the exterior world' (p. 25) and who experiences the world only through sensation (p. 26); it is, in short, 
the biological being whose inner world is undisturbed by the messiness of the outside world around it, its consciousness remaining without problems. 'This consciousness is not concerned with situating itself relative to an exteriority, does not grasp itself as part of the whole (for it precedes all grasping); it is a consciousness to which the term the unconscious ... or instinct corresponds' (Levinas, 1987, p. 26). The portrait of being that Levinas paints here does not represent an actual person who lives entirely in thoughtlessness, but rather depicts an aspect of the ego whose tendency is to totalise its reality, to see its reality as an extension of itself.

In contrast to this, Levinas situates the thinking being as one who is not only in and of the world, but who also recognises that world as exterior to it. Thus a thinking being is one whose inwardness is dependent upon the presence of another: the inner world is inner because there is an exterior world from which it is distinct, and to which it is opposed. Thought 'establishes a relationship with an exteriority which is not assumed. Qua thinker man is the one for whom the exterior world exists. From that moment on, his so-called biological life, his strictly inward life, is illuminated with thought' (Levinas, 1987, p. 27). One might say that 'man' is a totality no longer. The ability to think, then, is set in motion by something outside oneself, not, as in Arendt, by an interior split. As Levinas (1987) writes, 'thought begins with the possibility of conceiving a freedom external to my own... [Indeed] conceiving of a freedom external to my own is the first thought' (p. 28). What it means to think, for Levinas, is a consciousness of my outer world, a consciousness that others exist independently of me, a taking in of something unfamiliar and new. Moreover, consciousness itself is not possible without this exteriority.

Thought thus enables a relation between two, the self and the other, whereas thoughtlessness remains contained within the one, the same. With thinking established as that which is fundamentally connected to alterity-to a radical difference, to a not-me-Levinas simultaneously establishes the ethical character of judgement: the I or ego is susceptible to others in the outside world, to what lies exterior to it. It cannot think without the disruption that only an exterior relation can provide. So although the consequence of thinking may indeed be the conversation one has with oneself, that conversation is provoked into existence by otherness and is not self-constituting.

Recognising that we do not exist simply as I and other in the world, Levinas introduces the term 'third party' to formulate the link between thinking and judgement, or justice. This third party is the referent to human plurality which marks our social and political life. The third is the other's other, the other's neighbour, and hence my own neighbour as well. With this admission comes the difficult task of having to prioritise my attention and my responsibility with respect to my neighbours, in the plural. What was once an ethical responsibility, a total openness to the unique other, the third party, pulls me away from 'this proximity ... away from responsibility prior to all judgment' (Levinas, 1998, p. 195). Thus this necessity to judge founds thinking; it compels us to evaluate, compare, and thematise. We are already in the realm of justice as we think. 
Thus what do we think about as we judge? What kinds of considerations do we need to take into account, and what is it that we give up when we judge? It is worth quoting Levinas (1996) at length here:

\begin{abstract}
Doubtless, responsibility for the other human being is, in its immediacy, anterior to every question. But how does responsibility obligate if a third party troubles this exteriority of two where my subjection of the subject is subjection to the neighbor? The third party is other than the neighbor but also another neighbor, and also a neighbor of the other, and not simply their fellow. What am I to do? What have they already done to one another? Who passes before the other in my responsibility? What, then, are the other and the third party with respect to one another? Birth of the question.

... Comparison is superimposed onto my relation with the unique and incomparable, and, in view of equity and equality, a weighing, a thinking, a calculation, the comparison of incomparables...the necessity of thinking together under a synthetic theme... and through this, finally, the extreme importance in human multiplicity of the political structure of society, subject to laws and institutions... (Levinas, 1996, p. 168)
\end{abstract}

In Levinas's view, then, judgement does not have to be kick-started by thinking, for thinking is already caught up in the bonds of responsible justice by virtue of the self's encounter with exteriority. We can see here, then, that the thinking subject is one who of necessity betrays the ethical covenant of infinite responsibility even as that covenant informs how justice ought to guide our judgements. Justice, for Levinas, is thus an ideal for thought (elsewhere I have discussed this ideal in terms of Lyotard's interpretation of $\mathrm{Kant}^{8}$ ) which nonetheless grows out of the initial obligation the I has for the other. And it is I, the thinker, who has unique responsibility in the plurality of human faces, in the multitude of neighbours. It is the suffering, now, of my neighbours and not just the singular other, which moves me to judgement. As Richard Cohen has remarked, 'Love thy neighbour as thyself' is transformed by Levinas into 'Love thy neighbour is thyself'.

So, as with Arendt, adherence to rules or standards is not part of the substantive nature of justice for Levinas. Justice, although an ideal, has no content. It cannot tell us what to decide, it can merely inform us that, through a reminder of the initial obligation that we have for the other, we merely must decide. Thus it is not that universal principles, such as respect or human rights, have no meaning; rather that they cannot provide the content of our decisions: just as Catherine Chalier (2002) has noted with respect to Levinas, contra Kant, 'universal philosophical concepts are put to the test of singularity' (Chalier, 2002, p. 83). So, as Levinas claims, 'respect is not the result of justice... The one respected is not the one to whom, but the one with whom one renders justice' (Levinas, 1987, p. 43). Again with Arendt, Levinas posits the intersubjective element of justice as a co-endeavour amongst equal subjects who always must be reminded that I am singularly responsible to unique others and their suffering.

In this sense, then, I read thinking as central in judgement not only because of what thinking can do (critique, challenge, reflect), but that it does so fundamentally in relation to human plurality. Thinking has a fundamentally cosmopolitan quality. Thought is therefore not simply a flight into solitude, but a 
relation across radical difference where my thinking is enabled by the provocation of others. This means that although thinking is a distinct form of conversation, it nonetheless is occasioned by the conscious recognition of exteriority and the freedom of others. Thus both Arendt and Levinas are right in asserting that rules or standards (morality, quite simply) are not the stuff of judgement; rather it is the unique thinker who is responsible for the judgements she makes.

\section{Thinking cosmopolitan in education}

In proposing that 'thinking cosmopolitan' provides us with some insight into judgement, I am wary of promoting yet another rule or standard against which teachers evaluate their own judgements. Instead, I think we would do well to think, rather, of judgements as moments that fix thinking in time, that implicate teachers in the here and now of their work. For judgement is, ultimately, about implication: it is a definite decision that breaks with the duration of thought. And it reveals precisely the point where teachers feel the pull between the professional and the personal most profoundly: judgement commits 'me' to something. There is a basic paradox to be faced in teaching when it comes to judgement, for if judgement is that which exceeds rules and devotes itself to particular cases, then it is clear that teachers must perform as teachers in ways that cannot do justice to others. By this I mean that teachers' decisions often are made in the context of the rules of the profession and the culture of the school, with the result that the particularities of a case are neglected in the exigency of coming to a decision. Thought is not always possible in teaching. But how much thoughtlessness can we tolerate, and how much can we hide behind the veil our professional roles afford us?

It seems clear that where we draw that line has precisely to do with personal, not professional, judgement. It is not that all professional judgement is an unthinking reliance on rules and standards. Indeed, I would hope that a notion of the professional, of the teacher's role itself, could allow for the paradoxes and tensions teachers often experience. Moreover, I would hope too that that role could also incorporate personal aspects of the teacher herself. But, in cases of a sensitive nature, such as cultural conflict, for example, where a cosmopolitan ethic cannot provide us with a useful guide, then we also seem to require a much fuller language for how we make judgements in ways that do not forget the face of justice in the process. For it is precisely here where teachers are most likely to fall back on routine and procedure in an attempt to escape the discomfort and unease that conflicts entail.

Given the kind of work teachers do, there is often not a lot of time for thinking and so we need to reflect on how we can propose a thoughtful orientation to our judgements; that is, to think about our roles, as opposed to letting those roles determine our thinking. Such a thoughtfulness, whose nature I hope has now become clear, refuses both the simplicity of self-righteous moralising and the anonymity provided by standards and rules. It is a thoughtfulness that carries within it a cosmopolitan sense: a thought that is born from others who are my neighbours. 
And so, how do teachers carry out judgements concerning complex matters of values, rights and equality, for instance, without falling back unthinkingly on abstract rules? It seems to me that 'thinking cosmopolitan', as opposed to 'thinking according to cosmopolitanism', allows us some room for acknowledging the ideal of justice that prevails in making judgements and puts human diversity at the centre of what too often appears to be a solitary enterprise. For cosmopolitanism, it seems to me, is precisely about an openness to the indefinite; and if we are going to attempt to inaugurate forms of belonging that resist the narrow nationalisms that have thus far shaped so much educational content, then it means having to think 'without a banister', as Arendt was fond of saying (cited in Arendt, 2003, p. xxxvii). And this includes even those banisters - like cosmopolitanism - that we believe actually might be of the most help.

\section{Acknowledgements}

I would like to acknowledge the funding provided by the Swedish National Research Agency for the project Gendering the Cosmopolitan Ethic: A Feminist Inquiry into Intercultural and Human Rights Issues in Education, which made the writing of this paper possible.

\section{Notes}

1. Breckenridge et al. (2002) write, 'specifying cosmopolitanism positively and definitively is an uncosmopolitan thing to do' (p. 1), precisely because it invokes an openness to the indefinite and gestures to an unknown 'beyond' of the nation-state.

2. Although I am focusing here on the specifically European features of cosmopolitanism, I also wish to draw readers' attention to the way this discourse is not necessarily purely western. See, for example, Zubaida (2002) and van der Veer (2002) in Vertovec and Cohen (2002) for discussions of cosmopolitanism outside the west. My use of the term 'ethic' here is not meant to suggest that all writers who advocate for cosmopolitanism do so under the name of an 'ethic', but they do commonly agree on a shared set of values that are central to their cosmopolitan outlook, and it is this to which I am referring: world citizenship, empathy with global 'neighbours', commitment to human rights, respect for human diversity in all its manifestations.

3. Martha Nussbaum (2003), for one, interweaves this attention to cultural pluralism with a commitment to universal principles of human rights in her call for educational reform. Moreover, calls for global or world citizenship in education which similarly take up the twin projects of human rights and respect for cultural diversity have proliferated in recent years (Osler and Starkey, 2003; Noddings, 2004; Kemp, 2005).

4. For a fuller discussion of these issues, see Todd (in press). Also, Derrida (2002) identifies yet another contradictory imperative within cosmopolitanism: conditional and unconditional hospitality. The latter is that which cosmopolitanism offers to all people, regardless of origin or residence; the former is the inevitable limitations placed upon one's right of residence in a specific territory, land, or state.

5. For differences within the literature on cosmopolitanism, see for example Derek Heater's (2002) discussion, which takes a more equivocal position and focuses on the pros and cons of cosmopolitan and communitarian arguments with respect to world citizenship. 
Appiah (2006), in his discussion of cosmopolitanism and its ethical dimensions, focuses on commonalities across differences (particularly with respect to certain 'universal' values) and makes appeals to 'humanity' without sufficiently addressing the specific tensions between rights and human pluralism that inevitably arise when discussions are forged on how and who is to decide on what is common between us.

6. See Arendt's discussion on these points in more detail in the first book of The life of the mind: Thinking (1978).

7. Although Arendt (1978) discusses in Willing, the second book in The life of the mind, that the I returns to the world in action where 'a We is always engaged in changing our common world, stands in the sharpest possible opposition to the solitary business of thought, which operates in a dialogue between me and myself' (p. 200), she nonetheless does not attribute to the Will the capacity to aid in making judgements. Will, though central to Arendt's conception of political action and freedom, is little discussed in direct relation to the connection between thinking and judgement.

8. See Todd (2007).

\section{References}

Anderson-Gold, S. (2001) Cosmopolitanism and human rights (Cardiff, University of Wales Press). Apel, K-O. (2000) Globalization and the need for universal ethics, European fournal of Social Theory 3(2), 137-155.

Appiah, K.A. (2006) Cosmopolitanism: Ethics in a world of strangers (New York, Norton).

Arendt, H. (1978) The life of the mind (New York, Harcourt) (original work published 1971).

Arendt, H. (1992) Lectures on Kant's political philosophy (Chicago, IL, University of Chicago Press).

Arendt, H. (1994) Eichmann in Ferusalem: A report on the banality of evil (New York, Penguin) (original work published 1961).

Arendt, H. (2003) Responsibility and judgment (New York, Schocken Books).

Bauman, Z. (1993) Postmodern ethics (Oxford, Blackwell).

Beck, U. (2006) Cosmopolitan vision (Cambridge, Polity Press).

Breckenridge, C. A., Pollock, S., Bhabha, H. K. and Chakrabarty, D. (Eds) (2002) Cosmopolitanism (Durham, NC, Duke University Press).

Chalier, C. (2002) What ought I to do? Morality in Kant and Levinas (J. M. Todd, Trans.) (Ithaca, NY, Cornell University Press).

Derrida, J. (2002) On cosmopolitanism and forgiveness (M. Dooley and M. Hughes, Trans.) (London, Routledge).

Felman, S. (2002) The furidical unconscious: Trials and trauma in the twentieth century (Cambridge, MA, Harvard University Press).

Heater, D. (2002) World citizenship: Cosmopolitan thinking and its opponents (London, Continuum). Kemp, P. (2005) Världmedborgen: Politisk Och Pedagogisk Filosofi för Det 21 Århundradet [World citizens: Political and educational philosophy for the 21st century] (J. Retzlaff, Trans.) (Göteborg, Daidalos).

Levinas, E. (1987) The ego and the totality, in: A. Lingis (Ed.) Collected Philosophical Papers (The Hague, Martinus Nijhoff), 25-45.

Levinas, E. (1996) Peace and proximity, in: A. Peperzak, S. Critchley and R. Bernasconi (Eds) Basic philosophical writings (Bloomington, IN, Indiana University Press), 161-169.

Levinas, E. (1998) Uniqueness, in: Entre Nous: on Thinking-of-the-Other (M.B. Smith and B. Harshav, Trans.) (New York, Columbia University Press), 189-196.

Noddings, N. (Ed) (2004) Educating for global awareness (New York, Teachers College Press).

Nussbaum, M. (2003) Cultivating humanity: A classical defense of reform in liberal education (Cambridge, MA, Harvard University Press) (original work published 1997). 
Osler, A. and Starkey, H. (2003) Learning for cosmopolitan citizenship: theoretical debates and young people's experiences, Educational Review 55(3), 243-254.

Todd, S. (2007) Promoting a just education: dilemmas of rights, freedom and justice, Educational Philosophy and Theory. Available online at: http://www.blackwell-synergy.com/doi/full/10.1111/ j.1469-5812.2007.00310.x. (accessed 28 February 2007).

Todd, S. (in press) Ambiguities of cosmopolitanism: difference, gender and the right to education, in: K. Roth and I. Gur Ze'ev (Eds) Education in the era of gobalization (Dordrecht, Springer/ Kluwer Publishing).

Vertovec, S. and Cohen, R. (Eds) (2002) Conceiving cosmopolitanism: Theory, context, and practice (Oxford, Oxford University Press). 